
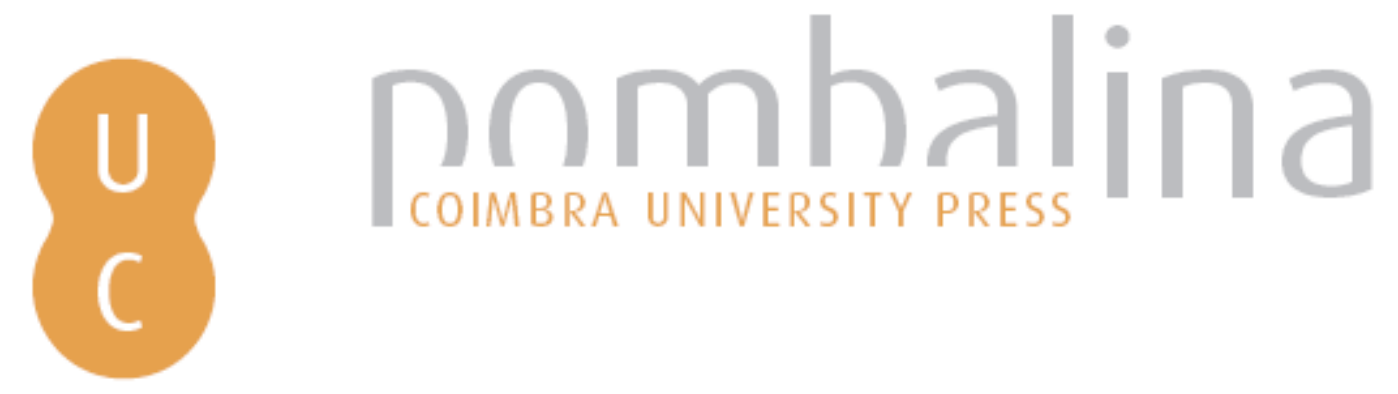

\title{
História do predestinado peregrino e de seu irmão precito (1685): os jesuítas como transmissores de saberes no Brasil colonial
}

\author{
Autor(es): $\quad$ Massimi, Marina \\ Publicado por: Imprensa da Universidade de Coimbra \\ URL \\ persistente: URI:http://hdl.handle.net/10316.2/38441 \\ DOI: $\quad$ DOI:http://dx.doi.org/10.14195/978-989-26-0764-1_5 \\ Accessed : $\quad$ 26-Apr-2023 14:43:22
}

A navegação consulta e descarregamento dos títulos inseridos nas Bibliotecas Digitais UC Digitalis, UC Pombalina e UC Impactum, pressupõem a aceitação plena e sem reservas dos Termos e Condições de Uso destas Bibliotecas Digitais, disponíveis em https://digitalis.uc.pt/pt-pt/termos.

Conforme exposto nos referidos Termos e Condições de Uso, o descarregamento de títulos de acesso restrito requer uma licença válida de autorização devendo o utilizador aceder ao(s) documento(s) a partir de um endereço de IP da instituição detentora da supramencionada licença.

Ao utilizador é apenas permitido o descarregamento para uso pessoal, pelo que o emprego do(s) título(s) descarregado(s) para outro fim, designadamente comercial, carece de autorização do respetivo autor ou editor da obra.

Na medida em que todas as obras da UC Digitalis se encontram protegidas pelo Código do Direito de Autor e Direitos Conexos e demais legislação aplicável, toda a cópia, parcial ou total, deste documento, nos casos em que é legalmente admitida, deverá conter ou fazer-se acompanhar por este aviso.

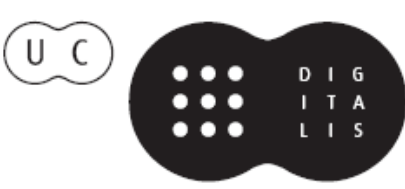


Departamento de Psicologia

Universidade São Paulo, Campus de Ribeirão Preto

mmassimi3@yahoo.com

\author{
História do Predestinado Peregrino e de seu Irmão Precito (1685): \\ Os Jesuítas como Transmissores de Saberes no Brasil Colonial
}

\title{
Marina Massimi
}

\section{Premissas}

Na perspectiva dos autores da Companhia de Jesus que atuaram no contexto luso-brasileiro da Idade Moderna (MASSIMI, 2002 a, 2005b, 2008c, 2010b), os processos psicológicos são tomados como dimensões da experiência humana. Por experiência entendem uma forma de conhecimento adquirida após o agir (modum operandi) e o precedente (e/ou consecutivo) pensar (modum cogitandi) com envolvimento de todas as potências anímicas e que conduz à verdade e ao bem, conforme a formulação sintética fornecida por Góis no Comentário Conimbricense à Ética aristotélica: "Aquilo que pode ser experimentado [quid potest ab aliquo experi] por alguém e alcançar a natureza de fim em relação a alguém, pode ser-lhe bom e conveniente" (GÓIS, 1957/1593, p. 69).

Ao abordar o universo sócio-cultural do Brasil do período colonial, marcado pela predominância da oralidade, deve-se lembrar que em muitos casos o universo das práticas (de natureza social, religiosa, cultural) é transmissor de um específico universo do pensável (CERTEAU, 2000). Deste modo, também o objeto de nosso estudo, ou seja, os saberes psicológicos são transmitidos e aprendidos pela participação nas práticas sociais: dentre elas, os jesuítas utilizam-se especialmente do ensino e da pregação.

O empenho pedagógico leva os jesuítas ao emprego de diversos recursos culturais disponíveis na época: teatro, música e canto, poesia, narrativa. Dentre eles, escolhemos uma fonte narrativa cuja difusão foi ampla e cujo objetivo era a transmissão da "arte de viver" a partir da concepção de pessoa proposta pelos jesuítas: a novela alegórica História do Predestinado Peregrino e de seu irmão Precito (1685) obra de um expoente da Companhia de Jesus no Brasil, padre Alexandre de Gusmão, baiano, diretor do Colégio do Menino Jesus de Belém em Cachoeira do Campo, local próximo de Salvador da Bahia.

$\mathrm{O}$ autor, nascido em Lisboa em 1629 e falecido na Bahia em 1724, vindo ao Brasil aos dez anos de idade, entrou na Companhia no Colégio da Bahia em 1646 e formado nesta instituição religiosa, ocupou vários cargos importantes em diversos colégios: mestre de noviços, docente em humanidades, prefeito de estudos no Rio de Janeiro, reitor do colégio de Santos, e depois da Bahia e por fim provincial do Brasil. Fundou nas proximidades de Salvador, à margem do Rio Paraguaçú, perto do centro urbano 
de Cachoeira, um Seminário chamado de Belém, instituído como escola provincial, no ano de 1686, Tratava-se de um estabelecimento considerado sui generis, para onde concorriam alunos de toda parte do Brasil, principalmente dos recôncavos baianos, pobres e filhos de abastecidos fazendeiros. Tratava-se do primeiro internato estabelecido no Brasil, onde ao longo de setenta e três anos receberam a primeira educação e ensino acerca de mil e quinhentos estudantes brasileiros.

Gusmão foi autor de numerosas obras que tiveram ampla difusão no Brasil da época: destacamos entre elas, a Arte de criar bem os filhos na idade da puerícia (Lisboa, Deslandes, 1685), a Escola de Belém, Jesus nascido no Presépio (Évora, Oficina da Academia, 1678), o Menino Christão (Lisboa, Deslandes, 1695), Maria Rosa de Nazaret nas montanhas de Hebron, a Virgem nossa Senhora na Companhia de Jesus (Lisboa, Deslandes, 1715), Eleição entre o bem e o mal eterno (Lisboa, Oficina da Música, 1720), O Corvo e a Pomba da Arca de Noé no sentido Alegórico e moral (Lisboa, Bernardo da Costa, 1734).

História do Predestinado Peregrino e de seu irmão Precito (1685) é uma novela alegórica, no sentido dela em seu conjunto ser uma grande metáfora da existência humana, podendo ela ser analisada sob diversas perspectivas: literária, retórica, pedagógica, teológica, etc. Em nossa abordagem, pretendemos evidenciar seu caráter de compêndio seja dos saberes acerca da pessoa e de seu dinamismo psíquico, conformes à doutrina aristotélico-tomista reinterpretada pelos filósofos da Companhia, especialmente os Conimbricenses e transmitidos pelos jesuítas no Brasil da Idade Moderna; seja das práticas comunicativas utilizadas para realizar este objetivo e disponibilizadas pela tradição do gênero retórico em suas diversas facetas (pregação, pedagogia, imaginêtica) (SANTOS, 2004).

\section{O ENREDO E AS PERSONAGENS DA NOVELA}

A novela é destinada à leitura e à escuta por parte de quem, não possuindo a instrução para ler e escrever podia ouvir a narrativa por boca de leitores mais cultos. Visa proporcionar ao destinatário "um roteiro de vida ou morte sempiterna, para que conforme a ele governe seus passos" (1685, prólogo): nela o leitor encontraria um espelho onde "ver" sua própria condição e, se for necessário, posicionar-se para uma mudança de rumo. A escolha de narrar a história em forma de parábola, utilizando-se dos recursos retóricos da metáfora e do exemplo, pretende "mover a curiosidade do leitor" (idem) e imitar o modo de transmissão doutrinaria da tradição cristã desde suas origens.

A novela propõe um roteiro metafórico cuja significação iremos investigar a seguir. Para tanto será importante compreender o topos da peregrinação enquanto prática e enquanto figura, no horizonte do universo cultural em que a novela foi construída.

\section{A PEREGRINAÇÃo NO UNIVERSO DAS PRÁTICAS}

A novela protagonizada por dois irmãos, Predestinado e Precito, é organizada em seis partes correspondentes a seis lugares imaginários (cidades), por encarnar uma espécie de topologia ideal desenhada pela imaginação e pela memória, conforme a longa tradição da arte da memória e a mais recente da composição do lugar inaciana; podendo ser os lugares de destino do percurso, ou Jerusalém, ou Babilônia. Desse 
modo, representa-se "a história de todo aquele que seguindo os passos, que nesta vida leva, se seguindo o caminho que tomou, ou se salva ou se condena” (prólogo).

Os dois protagonistas empreendem uma longa caminhada direcionada a alcançar a cidade onde estabelecer sua morada definitiva e cujo percurso atravessa ambientes geográficos de vários tipos: colinas, vales, centros urbanos, etc. Trata-se de um movimento corporal que adquire um claro significado simbólico, ao representar o percurso de cada existência humana marcado por uma temporalidade linear, ou seja tendo uma origem e um destino. Com efeito, o gesto remete a uma prática universal: a peregrinação tem origem muito antiga e amplamente difundida, praticada em diversas culturas e contextos geográficos do Oriente e do Ocidente, desde a antiga Grécia e Roma, até ao Egito e a China e Índia. A viagem em busca do centro, ou volta à pátria esquecida, ou perdida constituem-se entre os grandes arquétipos míticos da humanidade, presente nas literaturas, lendas, religiōes de todos os tempos e de todos os povos do mundo. Viagem pode indicar seja deslocamento de um lugar para outro, seja passagem do mundo corriqueiro para uma dimensão "outra" da vida, para o sagrado. $\mathrm{Na}$ maioria dos casos, trata-se de práticas de natureza religiosa, associadas a alguns locais tidos como sagrados (pela presença de sinais do sagrado tais como: manifestações extraordinárias ali ocorridas, um santuário, uma imagem, etc.) e que exigem dos participantes um ato voluntário de abandono dos lugares pátrios, dos afetos e dos hábitos da vida corriqueira, para deslocar-se ao longo de um percurso que em muitos casos poderá ser longo e perigoso, tendo como destino o referido local sagrado. Os participantes são chamados peregrinos: em sua origem latina, a palavra deriva do verbo peragere que significa: mover-se sem trégua, aperfeiçoar e levar ao termo. Assim o peregrino não é simplesmente estrangeiro, viajante, sem pátria. Sua verdadeira pátria é a meta, o destino de seu caminhar; sua vida se identifica com a peregrinação da terra do exílio até a pátria. Ao empreender o caminho, o peregrino sempre carrega em si uma espera, um pedido, uma exigência: conseguir a realização de um desejo; encontrar ou aprofundar o sentido de sua vida; a cura de uma doença, etc. (OURSEL, 1979; CARDINI, 1991).

No Brasil, esta prática foi e é muito difundida, comum entre os portugueses, como também enraizada na tradição indígena, onde as peregrinações em buscas de uma “Terra sem males” eram costumeiras (ELIADE, 1991). No Norte do País, a crônica do padre jesuíta J.F. Bettendorff (1687/1919) registra a existência desde 1698 de romarias para a vila de Vigia, onde era guardada uma imagem milagrosa da Virgem de Nazaré, a que deu origem ao culto do Círio de Nazaré vivo ainda hoje em Belém e outras cidades do Pará e também difundido pelas comunidades de emigrantes paranaenses em vários outros locais do Brasil. Outros centros importantes de romaria no Brasil são: São Francisco de Canindé, em Canindé, no Ceará (a esta inspira-se a composição musical de Humberto Teixeira e Luiz Gonzaga: A estrada de Canindé); o famoso santuário de Bom Jesus do Bonfim em Itapagipe, na cidade de Salvador; o santuário de Nossa Senhora dos Impossíveis em Patu no Rio Grande do Norte; o santuário de Bom Jesus da Lapa em Pirapora, no rio São Francisco; o túmulo do Padre Cícero em Juazeiro do Norte, no Ceará, o santuário de Nossa Senhora da Penha, em Vitória, Espírito Santo; o santuário de Bom Jesus de Pirapora no estado de São Paulo; o Santuário de Nossa Senhora da Piedade, Minas Gerais, e o Santuário Nacional de Nossa Senhora Aparecida. 


\title{
A peregrinação como dispositivo retórico
}

Segundo CARRUTHERS (2006), a dimensão pedagógica da pratica da peregrinação consiste em proporcionar o processo denominado de ortopraxi: a construção de uma experiência disciplinada que permite ao usuário identificar-se a si mesmo com base numa vivência reconhecida como original e constitutiva. A ortopraxi era comum nas comunidades monásticas medievais, cuja documentação é estudada por Carruthers. Segundo a autora, as peregrinações, freqüentes naquela época, para determinados lugares e as procissões de fieis seguindo imagens sagradas nos andores não eram relevantes tanto pela autenticidade histórica dos lugares e dos simulacros quanto pelo fato de que estas práticas proporcionavam o reconhecimento de imagens da memória. Desse modo, "a atividade física do deslocamento de um lugar para outro, espelhava fielmente a atividade mental na qual se empenhavam os participantes da procissão" (2006, p. 68, tradução nossa). As imagens eram reconhecidas não tanto pela descoberta do significado e sim pela função, utilizadas como suportes para o pensamento. A forma estética e os apelos sensoriais e afetivos por elas suscitados, deviam ser funcionais ao exercício da reflexão. A criação das imagens mentais não era sugerida tanto pela imitação de objetos tidos como representativos da realidade, quanto pela função cognitiva desempenhada $\left({ }^{1}\right)$. A construção das imagens obedecia não a regras de conteúdo e sim de forma, devendo servir para compor relaçôes e redes de relaçôes úteis para a retenção dos conceitos na memória. Na peregrinação, o itinerário, os lugares e as imagens encontradas pelo transeunte adquirem um significado alegórico. SANTOS (2004) frisa a importância desta tradição no contexto ibero-lusitano:

\begin{abstract}
"Nas primeiras décadas do século XVII, em Portugal, (...) os livros de pastores, mais exatamente entre 1601 e 1626, recorreram simultaneamente ao tema (ndr: da peregrinação) e ao recurso retórico. Da Primavera (1601) de Francisco Rodrigues Lobo a Os Campos Elíseos (1626) de João Nunes de Vasconcelos, a viagem, umas vezes no sentido de uma espécie de deambulação espiritual, outras como desterro, contribuía para a organização deste modelo narrativo. $\mathrm{O}$ mesmo ocorre, pelo que se prende com o uso da alegoria ou de processos alegóricos, nas variadíssimas tipologias discursivas que, prolongando filóes que a Idade Média tinha desenvolvido, atravessaram os séculos XVI e XVII, passando até pela provável matriz alegórica dos «Exercícios Espirituais», como marca impressiva da leitura de El Pelegrino de la vida humana (Toulouse, 1490) por Inácio de Loyola” (SANTOS, 2004, p. 588).
\end{abstract}

Gusmão faz uma referência explicita no texto à arte da emblemática de ALCIATI (1685, p. 135), e, sobretudo, conforme ressalta SANTOS (2004, p. 592), utiliza-se na construção da obra do "conjunto de saberes tributários da emblemática". De modo

${ }^{1}$ De fato, conforme reconhecido também pela psicologia experimental contemporânea, um elemento pontual é mais facilmente localizável se pertencer a um conjunto (por exemplo, pode-se mais facilmente localizar uma estrela numa figura de constelação, como o urso, o carro, o cruzeiro, etc.); ou se pertencer a uma narrativa. A eficácia mnemônica é aumentada quanto mais as imagens forem afetivamente intensas e cognitivamente inusitadas. Os estudos de Carruthers mostram que os processos cognitivos e os métodos para aprender a pensar, utilizados pelas culturas orais do Ocidente, pressupunham a articulação entre memória, imaginação, sensibilidade, afeto, pensamento e decisão: subentendia-se, portanto, uma específica concepção do dinamismo psíquico e do processo de conhecimento. 
que "o fundamental caráter alegórico" da mesma "lhe advém do persistente recurso à explicação pormenorizada de pequenos quadros, formados, sobretudo, por «figuras»" com base nos "conhecimentos em áreas dependentes do complexo e afortunado filão constituído por emblemas, hieróglifos e empresas". E como ainda evidencia Santos, "tal opção não se reveste de qualquer singularidade, se enquadrada no apreço que a Companhia votou à Emblemática e no peso e importância que os jesuítas concederam aos «libri figurati»" (SANTOS, idem).

$\mathrm{Na}$ Idade Moderna, as imagens (pinturas, estátuas, emblemas, empresas, metáforas e alegorias, etc.), além de serem empregadas nas práticas culturais e religiosas tendo em vista sua eficácia em comunicar conceitos, agem como dispositivos retóricos que provocam nos destinatários determinada elaboração. A eficácia desta elaboração, por vez, depende da ativação das potências psíquica, especialmente a atividade sensitivo-imaginativa (sentidos internos), ordenada para alcançar o Fim Último. Na tradição cultural dos jesuítas, o emprego das imagens é amplamente recomendado: um dos Padres Gerais da Companhia, Francisco Borja, reitera que na prática religiosa da meditação, o emprego de imagens é importante:

"para proporcionar maior facilidade na meditação, ponha-se uma imagem que represente os mistérios evangélicos, e assim, antes de iniciar a meditação, mire-se a imagem e especialmente reconhecerá o que nela deve ser reconhecido, para considerá-lo na meditação de modo mais claro e para tirar maior proveito dela. Pois a função da imagem é semelhante ao oferecer a comida pronta para que seja comida, de modo que não resta a fazer senão o comer; de outro modo, pelo contrário, o entendimento irá discorrendo e trabalhando para representar o objeto da meditação com muito custo e trabalho. (Meditaciones para todas las dominicas y ferias del año y para las principales festividades, século XVI/1912, pp. 7 e seguintes, tradução nossa).

Retomando as relações entre as imagens e os processos mnemônicos, pode-se afirmar que é uma específica configuração e a posição nela ocupada pela imagem mental que permite a memorização. As redes e os lugares desta configuração pertencem a inventários sociais e mentais que proporcionam mapas de orientação do pensamento e das condutas. A imagem é assim uma espécie de veículo dos conteúdos da memória, sendo a imaginação usada para construir estes mapas e decifrar os percursos sugeridos.

Novamente, o uso da emblemática e dos saberes afins envolve a mobilização da potência anímica da memória, como também SANTOS (2004) enfatiza. Na novela de Gusmão, o recurso à memória tem objetivo pedagógico e persuasivo: trata-se do uso de "estratégias propiciadoras da "memória», como formas privilegiadas da persuasão". De fato, "as entidades alegóricas cumpriam a sua função de «auxiliares» da memória, preenchendo uma relevante dimensão pedagógica, num livrinho que, embora não contivesse imagens - tornando-se presumivelmente de circulação mais alargada, porque também mais barato - não deixava de aproveitar de um filão prestigiado, a emblemática" (SANTOS 2004, p. 595). Além disto, "na Historia do Predestinado Peregrino, a memória não se revela apenas um meio pedagógico" para potenciar "a capacidade de fixar as marcas do caminho da perfeição", mas é também "a característica fundamental do itinerário que conduz a Jerusalém". Com efeito, "para lá chegar, (...) o cristão deve recordar, em todos os momentos da sua vida, que o mundo é um teatro, a grandeza uma sombra: «jamais lhe podia sair da memória este pensamento: 
Deus tinha escolhido a pobreza e a humildade». Só «o eterno [é] o verdadeiro e todo o temporal engano» (SANTOS 2004, pp. 595-596).

Evidencia-se então que o pressuposto para a composição da "peregrinação" narrativa pela arte retórica com objetivo pedagógico é a articulação entre memória, imaginação, sensibilidade, afeto, pensamento e decisão. A novela de Gusmão é um exemplo desta articulação entre as potências do dinamismo psíquico funcional à mobilização de certo processo de conhecimento visando a transmissão de determinados valores.

\section{O uso retórico da palavra}

Outro aspecto significativo inerente à construção retórica da novela é o uso da palavra disposta segundo os ditames da arte retórica. Com efeito, na transmissão oral (pregação) e na transmissão escrita (novela), a dinâmica de ação da palavra retoricamente ordenada, assemelha-se. Como já assinalado, possivelmente a novela foi construída para ser não apenas lida como também ouvida. A palavra retoricamente ordenada age com eficácia no dinamismo psíquico dos destinatários realizando os objetivos pretendidos, a saber: deleitar, mover, ensinar os destinatários. Tais efeitos são obtidos pela mobilização das potências anímicas: os sentidos (externos e internos) evocam afetos e provocam as operaçóes do entendimento e da vontade.

Em suma, a novela parece ter sido construída por Alexandre de Gusmão como um recurso pedagógico a ser utilizado tendo por destinatários não apenas leitores como também ouvintes, suscitando efeitos similares aos proporcionados por um sermão, devido à composição ordenada de palavras e imagens segundo os ditames da arte retórica. A eficácia de sua ação junto aos destinatários é proporcionada pela mobilização articulada das potências do dinamismo psíquico que por sua vez permite o processo de conhecimento visando a transmissão de determinados valores. Desse modo, pode-se apreender a novela e sua temática como parte integrante do universo das práticas.

\section{A PEREGRINAÇĀo NO UNIVERSO DO PENSÁVEL}

\section{Os valores a serem transmitidos}

A novela e seu tema central (a peregrinação) possuem também significados conceituais que, como já vimos, pertencem a um amplo domínio espaço temporal. Trata-se de uma temática persistente na longa duração do tempo e em diferentes pontos do espaço geográfico e que também assume conotações diversificadas e específicas em diversas épocas históricas como também em diferentes tradições culturais, sociais e religiosas. No caso específico da novela de Gusmão, para o entendimento do significado que o conceito de peregrinação assume, devemos atentar aos valores que ela pretende transmitir. Com efeito, a peregrinação é tida como metáfora da vida humana entendida como percurso no tempo moldado por uma origem e uma direção a seguir em busca de um destino final. Neste sentido, os valores são inerentes a esta orientação do tempo humano, assinalando condutas a serem encarnadas para que o 
destino possa ser alcançado com proveito. Evidenciamos pela leitura notadamente dois valores fundamentais: a afirmação do papel da educação para a formação da pessoa; e a ação decisiva da liberdade como condição da ordenação da pessoa ao seu Destino.

\section{A importância da educação para a formação da pessoa}

Na novela, o papel da escola dos filhos é decisivo: a escola a ser escolhida pode ser a da verdade; ou a da mentira. Conforme a opção feita, obrem-se um diferente aprendizado: "eis que chegam das escolas os filhos de ambos referindo as liçóes, que naquele dia aprenderam. Os filhos de Predestinado referiam as excelências, que da santa Cidade de Jerusalém apregoavam os Profetas. (...). Os filhos de Precito repetiam as grandezas, que de Babilônia referiam as escrituras" (1685, p. 13). Ou seja, a escola proporciona o direcionamento de intenções e desejos de cada um com relação a um horizonte último, que é o próprio sentido da vida, metaforizado pelas duas cidades de Jerusalém e Babilônia. A partir disto, inicia o percurso da história pessoal e coletiva, a peregrinação.

A imagem da peregrinação em Jerusalém é muito cara ao próprio fundador da Companhia, Inácio de Loyola. Em sua autobiografia, narrada em terceira pessoa, ele, ao relatar os inícios de sua conversão, lembra que "notou (...) esta diferença: quando pensava nos assuntos do mundo, tinha muito prazer; mas quando depois de cansado, os deixava, achava-se seco e descontente". Pelo contrário, "quando pensava em ir a Jerusalém descalço, (...), não se consolava só quando se detinha em tais pensamentos, mas ainda, depois de deixá-los, ficava contente e alegre". Esta experiência proporcionara a Inácio um maior conhecimento de si mesmo ("discernimento"): "colheu, então, por experiência, que de uns pensamentos ficava triste e, de outros, alegre. Assim veio pouco a pouco a conhecer a diversidade dos espíritos que o moviam" (LOYOLA, 1555/1991, p. 23). É justamente assinalar estas diferenças o propósito da novela de Gusmão.

\section{A ação decisiva da liberdade}

A intenção do autor é a de assinalar o papel decisivo do livre arbítrio no delineamento da história pessoal, acento propositalmente colocado com o objetivo de contrapor-se a leitura teológica do mesmo tema realizada pelo protestantismo e condensada na obra O Peregrino. A viagem do cristão à cidade celestial (1678/2004) de John Bunjam (1628-1680 ?). Do objetivo do texto de Gusmão adentrar neste debate teológico são sinais os nomes dos dois protagonistas: Predestinado e Precito. A caracterização da diferença entre os dois irmãos, nascidos da mesma mãe e cuja origem assinala a condição universal do ser humano como peregrino, é dada não somente pelo nome, mas pelo fato de que "Predestinado era casado com uma Santa e honesta virgem, chamada Razão. Precito era casado com uma ruim e corrupta fêmea, chamada Própria Vontade". Em suma, o eixo da personalidade de cada um é diferente: no primeiro caso trata-se do uso da racionalidade; no segundo é a afirmação da própria vontade. E os adjetivos que qualificam ambas as figuras evidenciam a avaliação dada pelo autor acerca de cada 
uma delas: no primeiro caso se trata de uma virgem santa e honesta, no segundo de uma mulher ruim e corrupta.

Apesar destas diferenças, Gusmão busca frisar que a condição humana é dotada das mesmas possibilidades: ambos os peregrinos "preparam-se para o caminho de sorte, que costumam os peregrinos. Por hábito vestiram o da graça, que chama de batismal", nos ombros tinham uma capa de pele de cordeiro que simboliza o "Cordeiro de Deus que é Charis" (1685, p. 13), ou seja, a "Proteção Divina”; "na cabeça puseram o chapéu, que diziam Memória da salvação"; "na mão tomaram o bordão de peregrinos, a que chamam Fortaleza de Deus, cortado de uma árvore, que só no Paraíso nasce”. Nos pés "calçaram as alparcatas, das quais uma se dizia Constância, outra Perseverança, ao ombro lançaram o alforje cheio de bons propósitos; na cinta uma cabacinha, que chamam Coração cheio de um vinho, que dizem Conforto espiritual"; por fim, "na bolsa meteram três moedas, com que o mais se compra, que chamam Bem Olhar, Bem Penhor e Bem Falar" (idem).

Ao iniciar a viagem, ambos os peregrinos "saíram por uma porta, que só se abre para sair, e não para entrar” (p. 13). Deste modo, Gusmão assinala que a temporalidade da existência humana tem uma direção irreversível; o tempo que já se foi não volta mais.

Deve-se ressaltar que o exercício da liberdade humana ocorre no impacto com a realidade, ou seja, diante das circunstâncias da vida (metaforizadas pela imagem da floresta e da mata). Esta, como o autor assinala, é "cheia de mil despenhadeiros", e de "embaraços", "enfadonhos de passar" (1685, p.14). O uso de imagens do mundo da natureza para metaforizar situaçôes morais, ou interiores, ou referentes ao sagrado, é comum no período da Idade Moderna e na tradição jesuítica (MASSIMI, 2007). O discernimento acerca do melhor rumo depende da decisão acerca de uma meta reconhecida mais consoante ao desejo de felicidade e de realização que caracteriza o ser humano: ambos os peregrinos aspirar a serem felizes: tudo se joga na diferença que há entre amar a si mesmos enquanto destino (destinado), ou amar a si mesmo naquilo em que imediatamente nos espelhamos. Ambos irão empreender um processo trabalhoso, mas cada um posicionar-se-á conforme o que ama. Análogo é o percurso que ocorre nos Exercícios espirituais inacianos, onde a partir da segunda semana, o sujeito é provocado a ler seu próprio desejo e neste momento se faz presente a possibilidade do engano no discernimento (LOYOLA, 1982).

\section{A PESSOA E SEU DESTINO NO SABER DOS JESUÍTAS}

O que está em jogo é o destino da pessoa. Para tanto, é preciso entender o significado deste termo que no saber da tradição ocidental sintetiza o dinamismo humano nas suas dimensōes corporal, espiritual, psicológica, segundo as matrizes conceituais posta por Agostinho (414/1994), Aristóteles (século IV a/2006); Tomás de Aquino (1273/2001). As três dimensões deste dinamismo compóem unitariamente a pessoa, mas possuem movimentos próprios (MASSIMI, 2010a).

Os protagonistas da novela, Predestinado e Precito, encarnam a pessoa assim como concebida pela tradição cultural do ocidente cristão. Deste conceito os jesuítas se fizeram transmissores no contexto do Brasil da Idade Moderna, utilizando-se dos instrumentos culturais elaborados no Colégio das Artes de Coimbra e disponíveis em 
sua bagagem cultural. Dentre estes, destacam-se os tratados assim chamados de Conimbricences redigidos pelos professores do referido Colégio e que, foram utilizados para os estudos filosóficos nos colégios da Companhia no Brasil (MASSIMI 2002a). Os tratados são comentários dos textos gregos de Aristóteles. No caso do estudo antropológico e psicológico, evidenciam-se os seguintes textos: o comentário ao tratado De Anima (Sobre a Alma, GOIS 1602), o comentário ao tratado Parva Naturalia (Pequenas coisas naturais, GOIS 1593a), o comentário ao tratado Ética a Nicomaco (GOIS 1593b), o comentário ao De Generatione et Corruptione (Sobre a geração e a corrupção, GOIS 1607).

Já no Brasil, vários textos foram produzidos pelos jesuítas com o objetivo de transmitir a visão antropológica que embasava seus saberes e suas práticas: o Diálogo do Padre Nóbrega sobre a conversão do gentio $\left(^{2}\right)$ onde o jesuíta Manuel de Nóbrega aplica o conceito aristotélico-tomista de pessoa, de alma humana e de potências psíquicas (a saber, o entendimento, a memória e a vontade), para justificar a humanidade e a convertibilidade do índio. Trata-se de uma discussão, na forma do diálogo - modelo retórico este muito utilizado no século XVI - entre duas posições, ambas difundidas entre os jesuítas em missão no Brasil: uma, afirmando a convertibilidade dos índios, com base em sua comprovada posse de todos os elementos próprios da natureza humana, especialmente no que diz respeito à sua vida anímica; outra, questionando esta certeza a partir das grandes dificuldades e impedimentos opostos pelos próprios índios à evangelização. Duas personagens - Matheus Nogueira e Gonçalo Alves - representam estas duas visões. Num dos pontos altos da conversação, Nogueira, coloca como fundamento de sua esperança nas possibilidades missionárias da Companhia junto aos índios, a afirmação de que estes são a pleno direito, pessoas humanas, e afirma:

"Estou eu imaginando todas as almas dos homens uma, nos serem umas e todas de um metal feitas à imagem e semelhança de Deus, e todas capazes de gloria e criadas para ela, e tanto valem diante de Deus por natureza a alma do Papa, como a alma do vosso escravo Papana" (NÓBREGA 1551/1989, p. 237).

A afirmação de que os índios têm alma igual à dos homens europeus é comprovada pelo fato de que "está claro, pois a alma tem três potências, entendimento, memória e vontade, que todos têm”. (idem) Sendo o índio reconhecido como pessoa, póe-se o problema de cuidar para que se desenvolva nele uma consciência adequada de si mesmo e uma conduta condigna. Neste ponto, coloca-se a importância da educação: "Terem os romanos e outros gentios mais policia, que estes, não lhes veio de terem naturalmente melhor entendimento, mas de terem melhor criação, e criarem-se mais politicamente" (NÓBREGA 1551/1989, p. 240).

O tema da pessoa é central na obra do autor de nossa novela, Alexandre de Gusmão. Numa importante obra do significativo título Arte de criar bem os filhos na idade da puericia (1685b), dedicada a pais e mestres, compara os caracteres dos meninos aos metais das minas, os quais têm valor e consistência diferente: assim como alguns metais são mais fáceis de serem lavrados, ao passo que outros são mais duros, da

\footnotetext{
${ }^{2} \mathrm{O}$ texto encontra-se em NÓBREGA, M. (1551/1989).
} 
mesma forma, "os naturais, ou condições dos meninos, uns são melhores que outros, uns mais brandos e que facilmente se amolgam, outros mais rebeldes, que dificultosamente se disciplinam". Todavia, da mesma forma em que não há metal (mesmo sendo de baixa liga) que não tenha seu préstimo e valor quando lavrado pela arte, "assim não há condição de menino tão ruim, que não possa ser domada pela boa educação” (ALEXANDRE DE GUSMÃO, 1685b, p. 4).

Em outra obra, Eleyçam Entre O Bem E O Mal Eterno (1720), Gusmão recomenda o cuidado para com a alma: trata-se de uma atitude que não é óbvia, pois sendo a alma uma realidade invisível e que nos pede para ir além da aparência, mesmo quando "cremos, que há almas", "como as não vemos, com os olhos, por isso as não amamos". O sentido da vista nos revela a beleza do corpo, ao passo de que a beleza da alma nós é revelada pelos sentidos interiores. Este conhecimento é importante, pois "do conhecimento que tivermos das nossas almas depende o amor, que lhe devemos, e desse amor, a nossa salvação" (1720, p. 341). Ainda segundo Gusmão, a pregação jesuítica vem a ser instrumento privilegiado para possibilitar este conhecimento e remediar ao descuido de nós mesmos em que muitas vezes caímos.

Neste contexto, a História do Predestinado Peregrino e de sue irmão Precito (1685a), pretende evidenciar a importância deste cuidado de si e os métodos para atuá-lo, assim como os efeitos do descuido: a pessoa realiza-se a si mesma somente na medida em que se desenvolve de modo ordenado ao seu destino último. Assim, conhecimento da pessoa e prática de orientação da mesma para que o seu ser em potência se atue, coincidem na novela.

As três dimensões do dinamismo que compõem unitariamente a pessoa (corporal, psíquica, espiritual), são evidenciadas na história dos dois protagonistas da novela. Analisaremos cada um delas.

Antes de mais nada, é preciso atentar para o dinamismo corporal da pessoa cuja importância é enfatizada na novela, onde o gesto físico de peregrinar adquire uma conotação ampla envolvendo sentidos psíquicos e espirituais. Fato este em plena coerência com a concepção aristotélico-tomista acerca do movimento corporal nos seres humanos. Com efeito, segundo os Conimbricenses, a potência locomotora no homem é dirigida pela razão, diferentemente do que acontece nos animais onde é regida apenas pelo instinto. Ainda, segundo os Conimbricenses, é preciso conhecer a "compleição natural" do corpo de cada pessoa. Os saberes acerca da compleição natural dos corpos individuais se encontram em vários tratados elaborados pelos mestres jesuítas de Coimbra, mas, sobretudo, no Commentarii Collegii Conimbricensis Societatis Iesu, in Libro de Generatione et Corruptione (1607, pp. 661-664), no livro segundo, capítulo oitavo (Quaestio I, articulo II), onde se discutem as teorias dos médicos e dos filósofos acerca da diversidade dos temperamentos (Temperamentorum differentiae quae et quales sint). Segundo os autores, no temperamento uniforme, todas as quatro qualidades (calor e frio, úmido e secura) estão presentes em igual proporção. No temperamento disforme há distribuição não equilibrada das quatro qualidades. Os quatro tipos de temperamentos disformes são: o temperamento colérico, onde prevalecem o calor e a secura; o temperamento sangüíneo, onde prevalecem o calor e a umidade; o temperamento fleumático, onde há excesso de frio e úmido; o temperamento melancólico, onde predominam o frio e a secura. No mesmo livro e capítulo (Quaestio III), os autores recusam a teoria da determinação absoluta das diferenças individuais pelos fatores 
humorais, afirmando assim seu distanciamento da tradição galênica ortodoxa, ao evidenciar o papel da responsabilidade do sujeito quanto ao aperfeiçoamento e correção de suas inclinaçôes (MASSIMI 2000a; MASSIMI 2000b; MASSIMI 2010b).

Quanto ao dinamismo espiritual, a existência humana como peregrinação constitui-se em núcleo temático central da novela, conforme assinalado com clareza na parte conclusiva onde o autor fornece a chave de interpretação das metáforas utilizadas:

\footnotetext{
"Agora te pergunto a ti, que isto lês, isto, que em parábola te represento, não é o que na verdade passa entre nós? Não é verdade que todos somos irmãos, filhos todos do mesmo pai, que é Deus? Não é certo, que todos nesta vida e em quanto nela vivemos somos como Peregrinos, ou como desterrados, e que a nossa pátria é o Céu e a Terra desterro?” (1685a, p. 359).
}

Em primeiro lugar, Gusmão apela ao leitor como sendo "devoto": "eis aqui, devoto Leitor, o fim que teve o nosso Predestinado Peregrino de todos os seus caminhos" (1685, p. 359). Ou seja, a leitura implica não apenas o envolvimento das potências cognitivas como também atitudes espirituais, como a devoção. Em segundo lugar, o autor destaca a importância do destino escolhido pelos protagonistas: "eis aqui qual foi o termo de sua peregrinação; agora é bem, que confiras com o Irmão Precito, para que pelo sucesso de um e de outro vejas o caminho que levas, para conhecer o fim que te espera" (idem). Em terceiro lugar, assinala a dimensão dinâmica da condição humana como um todo: "todos somos nesta vida Peregrinos e algum dia há de chegar o fim de nossa peregrinação, o qual, ou há de ter salvação, ou de condenaçãa eterna" (idem). Em quarto lugar, como já vimos, a novela aponta que o destino e, portanto, o sentido de cada existência não é predefinido, mas depende do discernimento da pessoa na escolha da direção a tomar: "Pois se tu queres saber qual destes dois fins te espera, examina os passos de teu caminho. Se segues os passos de Predestinado, bem pode esperar o de salvação se segue os passos de Precito, bem podes temer o da condenação". Segundo Gusmão, a estória de Precito mostra que a capacidade do discernimento depende não apenas dos "bons propósitos" e da boa companhia, mas também do cuidado com a possibilidade dos enganos da própria vontade. Estes enganos podem levar a pessoa ao abandono seja dos propósitos e seja da companhia, de modo a ficar enredada pela vaidade, pela idolatria, pela soberba e por uma enganosa concepção do que seria a liberdade. Se imediatamente o engano se configura com uma aparência de "delicias", logo em seguida revela-se no seu aspecto real de "confusão" (1685a, p. 360) (figurada por Babilônia, cidade infernal). Pelo contrário, o desengano que leva ao discernimento correto da realidade, implica seguir o "conselho da razão", que endereça o caminhante a seguir "os passos de Cristo", aprendendo a viver as mesmas virtudes da divina pessoa: devoção, piedade, obediência, penitência, perseverança nas tribulaçôes, etc.. e chegando à "Cidade de Bethel casa de Deus e cidade da perfeição", governada pela caridade e enfim à "Jerusalém ditoso termo de sua peregrinação, onde vive eternamente com seu Rei, que é Cristo", "feito um de seus Bem aventurados Cidadãos" (1685a, p. 361).

Evidencia-se em suma na novela um ponto importante da concepção antropológica dos jesuítas: para que o ser humano seja íntegro, é preciso que a razão ordene o dinamismo humano; que a existência seja conforme à razão; e que a vontade seja submetida a uma alteridade e não se afirme por ela mesma. No âmbito estritamente 
jesuítico, trata-se da inaciana virtude da indiferença (MASSIMI, 2005a). Há, com efeito, duas possibilidades inerentes ao ser humano e constantemente colocadas diante da sua escolha: podendo ele viver ou conforme a razão; ou conforme a própria vontade. Por vez, estas conformidades originam duas posições diferentes, metaforizadas pelos filhos dos dois casais: "Tinha Predestinado seus dois filhos de sua esposa Razão, um macho por nome Bom Desejo e uma fêmea por nome Reta Intenção. Precito assim mesmo tinha outros dois filhos de Própria Vontade, um macho por nome Mau Desejo e uma fêmea por nome Torta Intenção" (1685a, p. 7). A saber, o desejo ou apetite (afeto) e o movimento da vontade (intenção), podem ser orientados pela razão e então são bons e retos; ou pela vontade própria sendo assim maus e tortos. E isto, como vimos, depende da educação na primeira infância conforme assinala o autor: "sabia de quanto dano era criarem-se os filhos de sua primeira idade com Vontade Própria” (p. 8). A razão é caracterizada como tendo "os olhos de vista tão perspicazes"; ao passo que a vontade própria é "toda feita de seu apetite, se em alguma coisa a contradiziam, notavelmente se exasperava. Era cega de ambos os olhos, como é toda Vontade, por isso a cada passo tropeçava" e "daquilo vinham os desgostos que tinha com todos" (1685a, p. 11).

\section{O DINAMISMO PSÍQUICO NA VISÃO DOS JESUÍTAS}

O percurso que até aqui fizemos esclarece a concepção jesuítica acerca das interações entre dinamismo espiritual e dinamismo psíquico, ou seja, o funcionamento das potências da alma, suas operações, suas doenças e seus remédios. Tais potências constituem-se na interface entre o corpo e o espírito. Com efeito, a ordenação da pessoa como um todo, demanda um funcionamento saudável do dinamismo psíquico indicado pelo rótulo de "potências da alma". É a partir da ocorrência de alguma desordem nelas que se instalam na pessoa as "más inclinações". Na viagem dos dois peregrinos, as potências são metaforizadas pela imagem de um aparelho hidráulico composto por fontes de água (estas podendo, ou não, estarem limpas), canais e regatos. Segundo o relato: "estas fontes não são outras que as duas potências principais de nossa alma, Entendimento e Vontade, donde todo o bem e todo o mal provêm" (1685a, p. 260). As operações delas ocorrem pela mediação de outras potências anímicas:

“ambas correm por dois canos que chamam Apetites Sensitivos, um tem por sobrenome Irascível e outro Concupiscível, os quais ambos se deságuam por onze regatos que chamam Paixões, cinco de Concupiscível se chamam Amor, Ódio, Desejo, abominação, Deleite, Gozo e Tristeza; os canos do Irascível se chamam Esperança, Desesperação, Ousadia, Temor, Ira e Indignação". (1685a, p. 260).

Análoga concepção do psiquismo de matriz aristotélico-tomista pode ser encontrada nos já citados tratados Conimbricenses, especialmente no Comentário ao De Anima, aos Parvas Naturalia e à Ética a Nicômaco. Nesses comentários, as potências psicológicas da alma são classificadas em cinco tipos: em primeiro lugar, a potência vegetativa com as funçôes nutritiva e geradora; em segundo lugar, a potência sensitiva, 
responsável pelo conhecimento sensível ${ }^{3}$ que atua pelos sentidos externos (vista, ouvido, cheiro, sabor, tato) e pelos sentidos internos. Estes são: o senso comum que tem a função de reunir as sensações dos cinco sentidos externos, distinguindo e comparando as sensaçōes entre si e é localizado na parte anterior do cérebro; a fantasia, que compõe e divide as sensaçôes entre si e é localizada no resto do cérebro, a potência cogitativa ou estimativa, e a memória. Em terceiro lugar, a potência apetitiva é formada pela potência apetitiva sensitiva orientada para os objetos sensíveis e singulares (ou seja, as paixôes, ou vida afetiva propriamente dita) e a potência apetitiva intelectiva, que depende da razão (a vontade). A potência intelectiva se compõe de conhecimento intelectual intuitivo (informação acerca de um objeto presente) e abstrativo (conhecimento de um objeto que não está presente).

Quanto ao nexo entre apetites e valores espirituais, os Conimbricenses, na Primeira Disputa da Ética (GÓIS, 1593/1957), ao discutir acerca da natureza do bem e do desejo, afirmam que o ato de apetecer evidencia a inclinação de todas as coisas para o bem, mediante prévio conhecimento sensorial. Este bem é o bem que é conforme a natureza do ente: todavia, no caso dos seres humanos, este bem pode ser por eles identificado com um dado objeto que não é conforme à reta razão e à lei de Deus (sendo Deus o bem maior). Ou seja, quando ao bem natural se opõe um bem maior, o homem, deve-se discernir e optar por este. Decorre que o sujeito que faz o mal, não quer o mal enquanto tal, mas "enquanto aparece bem, ou enquanto é deleitável por causa do uso da liberdade", ou seja, "debaixo de alguma imagem imperfeita de bem" (idem, p. 83).

Gusmão parece aderir a esta posição ao apresentar o dinamismo de Precito: a causa de seus desvios não é o exercício da vontade por si mesma, mas o fato dela ser mal direcionada, por não estar submetida a razão. De certo modo, a vontade de Precito regredira ao nível das paixōes, dos apetites sensitivos. Por isto, para o bem viver, torna-se decisivo o trabalho do cultivo dos apetites e das demais potências, e a identificação das suas "enfermidades" cujo desenvolvimento é descrito em pormenores por Gusmão. Ele retrata o adoecimento anímico, em analogia com as doenças do corpo, como uma "infecção" decorrente do fato que nas águas das fontes (potências) se infiltram as "más inclinaçôes". De modo que, "a primeira fonte, Entendimento, se infecciona com uns limos pegajosos que dizem Maus Ditames; a segunda fonte, Vontade, se infecciona com outros que se chamam Maus Afetos" (1685, p. 261). Desta infecção decorre que: "se o nosso Entendimento estiver infeccionado com ditames depravados, ou doutrinas diferentes" e "se a vontade estiver depravada com os afetos desordenados de nossas paixōes", ambos tornam-se incapazes de "acertar o entendimento com a verdade e a vontade com o bem" (idem).

Como vimos, as paixões são inclinaçōes do apetite sensitivo que movem a vontade. Todavia, "o apetite não move a vontade imperando-lhe" (GÓIS 1593/1957, p. 159), por tratar-se de uma faculdade psíquica inferior, ligada ao órgão corporal, que é material e como tal não tem domínio sobre uma potência superior e imaterial (em conformidade com a teoria aristotélica). O apetite move a vontade "por intermédio da noticia intelectiva que propõe" acerca do objeto ("se o objeto deve ser aceito, ou

${ }^{3}$ Este conhecimento é produzido por assimilação da imagem do objeto pelo sujeito: a imagem é primeiramente fornecida pelos sentidos externos (fantasma) e depois elaborada pelo intelecto (espécie inteligível), recebendo nesta etapa o nome de espécie sensitiva. 
rejeitado"). Deste modo, quando "a paixão do apetite tem interesse em que o intelecto, deste ou daquele modo ajuíze acerca da coisa" pode ocorrer que "a vontade, seguindo a decisão do intelecto, queira ou repudie o mesmo que o apetite". Além disto, pode ocorrer que "o apetite mova a vontade por meio da notícia do sentido interno que ele próprio segue, enquanto os fantasmas dos sentidos determinam o intelecto para a contemplação desta ou daquela cousa” (p. 159).

Nestes casos, é possível seja que o movimento aconteça de forma ordenada, seja que a vontade seja arrastada pelo apetite, de modo tal que não tenha poder para lhe resistir, quando este "for tão veemente que absorva absolutamente o uso da razão": apenas nesse caso o apetite move a vontade segundo uma causalidade necessária e determinista. Quando a paixão se apresenta desta forma na vida anímica, é uma inclinação do apetite intensa e desordenada a qual "perturba (...) e absorve o juízo". Então, "o conhecimento sensitivo" associado a este apetite, "de tal forma move o intelecto veementemente para pensar acerca do objeto da paixão (por exemplo, acerca da coisa que causa a dor ou o prazer), que lhe tira a faculdade de deliberar" (idem, p. 161). Trata-se, porém, de uma condição muito específica pois de modo geral "o movimento da vontade é livre na medida em que o juízo permanece integro e livre”. Tal posição é reiterada pelo comentarista também na quarta disputa do mesmo tratado, em que se discorre acerca do dinamismo da vontade: esta é livre quando "segue a precedente deliberação do intelecto" (p. 139). De outro modo, a ação do homem não se distingue dos atos dos animais. Por sua vez, a vontade move as demais potências "para o exercício dos seus atos" (p. 147).

Eis aqui descrito o processo vivenciado por Precito na novela: levado para Samaria por Engano, seu conselheiro, em primeiro lugar se hospeda na "casa da Vaidade" e a seguir por estimulo dos "seus dois filhos Mau desejo e Torta Intenção" resolve seguir o caminho da vaidade e adentra uma terra regida pelo velho "Vício", com os seus três governadores (concupiscência da carne, concupiscência dos olhos, soberba da vida). Nesta terra, Precito se hospeda no bairro de "Passatempo", "onde não havia outra ocupação, mais que jogos, risos e entretenimentos, onde não poucas vezes nasciam mil dissensos" (1685a, p. 247). Da união com a esposa "Própria Vontade", Precito gera dois filhos Desprezo e Estimação "e havendo de se aplicar a alguma arte, se aplicou Desprezo às coisas eternas e Estimação as coisas temporais”. Em conseqüência dos rumos escolhidos por Precito, ocorre um desequilíbrio interior das potências: "Dureza do Coração, Cegueira do Entendimento, Obstinação da Vontade", "de tal sorte que não parecia homem de razão" (idem, p. 247). Resulta, no fim, a "confusão" que o atormenta "com mil tristezas, desgostos e inquietações" e uma "serpente de terrível aspecto" metáfora da "própria Consciência", o envolve em "voltas e revoltas a que chamam Imaginações"; e morde seu coração com "três dentes": "a Vontade lhe atravessava o coração com uma obstinação ou desesperação eterna, (...); a Memória lhe mordia coração com a lembrança das delícias breves (...) pelas quais granjeara aqueles tormentos; e o Entendimento lhe atravessava o coração com a representação de seu Irmão Predestinado, que às portas de Jerusalém estava já alegre para entrar” (idem, p. 315). Em suma, Precito é o caso exemplar do desvio da vontade com relação ao seu alvo, desvio que acarreta a desordem dos atos humanos. 


\section{A ORDENAÇÃO DA VIDA ANÍMICA}

A desordem da experiência humana, assim configurada, é a "doença” que a formação jesuítica, proposta por Inácio e seus seguidores, busca "remediar" por meio de um trabalho sistemático de ordenação das dimensóes pessoais. Não se trata de neutralizar ou desconsiderar a ação das potências psíquicas, por elas serem elementos constitutivos da experiência humana. Na novela, por exemplo, no meio das circunstâncias da peregrinação, os caminhantes se deparam constantemente com as "paixões", metaforizadas pelas feras (lobos, leôes, raposas), que os acompanham ao longo do percurso inteiro. Trata-se de encontros inevitáveis. Ocorre, portanto, aprender a lidar com estes fenômenos de modo a torná-los elementos construtivos do desenvolvimento da pessoa: de fato, segundo os Conimbricenses, "as paixôes, se lhes antepusermos a razão como senhora (a que se submetem com obediência civil), podem se utilizar para a moderação e o equilíbrio e chamar para as obrigações das virtudes" (GÓIS 1593/1957, p. 199).

\section{Ordenação da razão e da vontade pelo desengano}

Na novela de Gusmão, os remédios propostos a Predestinado correspondem aos grandes pilares da pedagogia jesuítica: trata-se do bom uso da razão, orientada, em sua busca da verdade e do bem, pela moralidade (reta intenção e bom desejo). Esta por sua vez saberá ordenar bem vontade e afetos. Ao Predestinado é aconselhado entregar-se ao "cuidado da esposa Razão e dos dois filhos Bom desejo e Reta intenção" (1685a, p. 261). "Reta intenção" alimpará o entendimento e "Bom Desejo terá cuidado de ordenar bem a vontade" (idem). Na tradição jesuítica e de modo geral do cristianismo da Idade Moderna, este trabalho é chamado de "desengano". Na novela, o "Desengano" é uma personagem que aconselha Predestinado e que é caracterizado como aquele que "fixa os olhos em Verdade". Junto aos conselhos de Desengano, o peregrino recebe por um anjo uma tocha, feita de cera muito pura, "fabricada por umas abelhas, que chamam Potências da alma" com o pólen de "flores trasladadas do Paraíso ao jardim da Igreja Católica por indústria do seu próprio Jardineiro, que é o Espírito Santo” (idem). Ou seja, o trabalho do desengano é proporcionado, por um lado, pelo dinamismo anímico (as abelhas, a saber, as potências da alma, têm um papel ativo no processo) e, por outro, por um dado que são as "flores" provenientes do Paraíso, entenda-se a Graça. Aqui está colocada a posição teológica dos jesuítas acerca da relação entre liberdade humana e iniciativa divina, relação esta questionada pela doutrina do protestantismo que reafirma com força a predominância da Graça (BUZZI 2000).

A crença na função decisiva das potências da alma no percurso do desengano demanda o conhecimento de sua atuação e isto justifica a atenção reservada à dimensão psicológica na antropologia jesuítica. O desengano enquanto entendimento verdadeiro da realidade é abordado também na oratória sagrada, que é o instrumento por excelência deste conhecimento (vide: MASSIMI, 2005).

$\mathrm{Na}$ novela, filhas e filhos do Predestinado, bem como outras personagens que o acompanham, são metáforas dos elementos do processo anímico associado ao desengano. Em primeiro lugar, Curiosidade e Devoção. A Curiosidade leva Predestinado ao conhecimento das "coisas memoráveis" contidas na cidade de Belém (chamada também 
de cidade do desengano), ou seja, o conhecimento intelectual de fatos e protagonistas da história sagrada. Ao passo de que Devoção leva ao conhecimento dos "lugares" desta mesma história; o que nos remete ao procedimento da ortopraxis estudado por CARRUTHES (2006) e já citado, ou seja, o exercício da memória topográfica. Em segundo lugar, o pensamento e a consideração piedosa abrem caminhos ao conhecimento da verdade pela razão: na novela, Predestinado é agraciado por um anjo bom com o dom de um cabalo mais ligeiro do que o vento, o Pensamento; e uma "guia muito prática", Consideração Pia. Os dois levam-no a o monte da cidade de Desengano, casado com uma senhora santa e muito ilustre, chamada Verdade.

A articulação entre as potências anímicas no exercício do desengano é ilustrada por Gusmão ao retratar o "Palácio do Desengano", no capítulo sexto da novela, que Predestinado visita acompanhado por "Consideração Pia".

Em primeiro lugar, destaca—se a memória. Todos os acessos ao Palácio correspondem a atividades da memória aplicada a específicos objetos. Em primeiro lugar, a primeira ampla porta do palácio é a Memória da eternidade (podendo ser uma eternidade de glória, ou de penas); esta porta abre o acesso a um pátio de onde claramente se enxergam céu e terra (a saber, o conhecimento do temporal e do eterno). Nos quatro cantos do pátio estão quatro arcos, chamados de "Novíssimos do Homem", com quatro portas (memória da morte, memória do juízo, memória do inferno, e memória do paraíso). Trata-se em suma de uma memória voltada para acontecimentos definitivos da existência humana. No Palácio, existem outros objetos da memória, cuja apresentação paralisa o Peregrino e inviabilizam o caminho, apresentados na forma de quadros, a saber, as lembranças do passado, do presente e do futuro. Outros quadros também estão no Palácio, pintados pelo desengano e destinados aos transeuntes: referem-se a estórias de desengano, como a de Francisco Borja, que pela vista da Imperatriz morta ficou desenganado do mundo, deixando o Ducado de Gandia, e tomando o hábito da Companhia de Jesus. De fato, a representação pictórica dos exemplos do desengano é um recurso destinado a representar aos caminhantes as diversas possibilidades do destino humano. O objetivo destas representaçôes é que os transeuntes "contemplassem os exemplos daqueles, que com aquelas mesmas razōes se haviam desenganado" (1685a, p. 31).

A memória é complementar ao esquecimento, que deve se aplicar aos objetos maus. Todavia, se mal usado, o esquecimento vira doença, como acontece a Precito: trata-se de "um sangue tão maligno" "que era um pasmo de sentidos e potências a que os Médicos chamam Esquecimento, com o qual andava a modo estúpido, sem Lembranças de Deus, nem da salvação, nem sentia já os remorsos de consciência”. Esta doença fazia com que "tinha os sentidos muito espertos e as potências muito atentas" voltados para as aparências: "por isso sentia por extremo a perda de qualquer coisa temporal e pela perda das eternas nenhum sentimento mostrava" (1685a, p. 246).

Outra potência anímica envolvida no processo é o entendimento. Ainda no Palácio, há quatro câmaras, correspondentes às idades da vida associadas as quatro estaçóes do ano. Em cada uma delas, o desengano atua e assume feições e formas diferentes, "ora de Velho, ora de Mancebo, para denotar, que em todos os hábitos, estados, e idades se pode achar o Desengano" (1685a, p. 23). O trono do Desengano, no centro do Palácio, é a esfera do mundo girando por volta de dois eixos, a vida e a morte num movimento constante entre estes dois pólos ("qual começava seu movimento do pólo da vida, e acabava no da morte" [1685a, p. 24]). No globo do mundo estavam escritas duas 
palavras: tudo e nada, explicadas assim por Desengano: "O mundo tudo é nada, ou ao revés, nada é tudo o que é do mundo" (idem). Na apreensão deste movimento constante de alternância entre dimensóes opostas da realidade, a tomada de consciência de que a própria condição humana é submetida a estas mudanças, é central no desengano, conforme as palavras de sua figura personificada na novela: "Tempo há de vir, ò Peregrino, em que tu, que agora isto ouves, vives, comes, jogas, e te deleitas, hás de estar morto, feio, e hediondo debaixo de uma sepultura. Horrível caso, que hoje fomos vivos, e amanhã seremos mortos!" (idem).

Os atos da memória e do entendimento são eficazes na medida em que forem se acompanhados pelo uso correto dos sentidos que por sua vez depende da decisão da vontade. Dentre os sentidos, o mais importante é a vista. Com efeito, após visitar o Palácio, Peregrino é conduzido por Desengano numa montanha de onde pode contemplar o universo inteiro e é colocado diante de uma decisão a tomar: se ele usar os "óculos da carne", se detém na aparência das coisas; ao passo de que se usar os "óculos do espírito", as enxerga em sua consistência real. Colocando os primeiros, as riquezas aparecem a quem olha como "coisa de grande estimação"; mas utilizando os segundos, por serem mais cristalinos, quem olha "chega a penetrar as coisas mais remotas", ou seja, a realidade na longa duração desde sua origem até seu destino. Isto possibilita o juízo:

"Predestinado considerou a duração das coisas eternas, a brevidade das coisas temporais, a ânsia, com que os homens a estas se aplicam, a negligência, com que procuram as eternas, todas essas coisas lhe pareciam muito dignas de reparo, e de serem muito devagar meditadas. (....) e finalmente então viu claramente, quão falsas eram todas as esperanças do mundo, quão enganosas suas promessas, que só o eterno era o verdadeiro, e todo o temporal engano" (1685a, p. 44).

A boa aplicação do ouvido também é importante e requer a mobilização da atenção: de fato, é preciso ouvir com atenção e intenção. Neste ponto, Gusmão faz uma ressalva sobre a importância de ouvir bem o pregador, já que este como "médico das almas" promove o conhecimento desta e a cura das enfermidades do ânimo. Através da metáfora das virgens monstruosas encontradas na cidade de Nazaré (algumas com as orelhas no peito e outras com as orelhas em várias partes do corpo), Gusmão evidencia a importância de que a escuta da palavra ouvida aconteça em profundidade, e, portanto, seja algo inerente ao coração. Trazer "os ouvidos no coração" significa, com efeito, possuir "a verdadeira intenção e atenção" (1685a, p. 69). Gusmão aplica esta disposição ao modo de ouvir a pregação e ao exercício da mesma, e aproveita para dirigir uma critica a certos pregadores seus contemporâneos que tornam "a Palavra de Deus muito ornada de ricas peças, enfeitadas com lindas flores, seguida de copiosos concursos" (idem), mas sem apresentar a evidência de ver "os mistérios, que aqui vejo" (idem). Trata-se neste caso "não é a Palavra de Deus, senão Retórica humana" (idem). $\mathrm{O}$ uso correto dos sentidos externos depende também da diligência e disposição, que podem ser adquiridas através de três exercícios, que são Lição, Oração e Meditação. É peculiar e expressivo do carisma jesuítico o comentário de Gusmão a respeito das três personagens que figuram os três exercícios, de que "se bem sua própria habitação é lá no outro bairro, que chamam Claustro, com tudo também cá neste bairro Século se acham, por quem as sabe buscar" (1685a, p. 73). Ou seja, trata-se de uma proposta 
de orto-praxis possível a todos os homens que vivem no meio do mundo, e não apenas aos religiosos que vivem recolhidos. Gusmão descreve em pormenores cada uma das três práticas e os recursos a elas inerentes, representando-os sempre através das metáforas topológicas e das personagens alegóricas. A Lição "aplicada toda a um livro espiritual, habitava em uma formosa livraria toda de livros sagrados, devotos e honestos, e nenhum só livro de comédias, ou novelas se achava ali” (idem). Todavia, os livros não são eficazes sem a disposição do leitor:

"E para que os Peregrinos, que ali entrassem, soubessem como haviam de tratar e ter os livros daquela livraria estavam por cima escritas as palavras de Cristo, Quomodo legis? De que sorte lês? Lês para proveito, ou para passatempo? Se para passatempo, tempo perdido será; se para proveito, será grande, o que da lição espiritual tirarás" (idem).

O aproveitamento da leitura dos textos é possibilitado pelo uso de óculos especiais, feitos por um cristal chamado de Entendimento, ou Conceito; demanda-se a atitude do silêncio, (representado por um "velho muito calado", que introduz num "cubículo chamado Retiro") e de oração (representada por uma "velha faladora chamada Reza”). O peregrino é conduzido a seguir em outro Palácio, chamado da Oração, onde encontra uma jovem muito bela, "vestida de tela abrasada, para denotar os incêndios do Divino amor", com asas. Estas metaforizam "Afeto Pio, e Afeto Devoto, para significar a essência e a definição da Oração Mental, que é uma elevação da nossa mente a Deus, por devoto e pio afeto" (1685a, p. 78). Os sentidos movem-se em harmonia com os afetos.

\section{Ordenação dos sentidos internos pela composição de lugar}

Destaque especial é dado aos sentidos internos, cujo bom uso é proporcionado pelo método inaciano da Compositio Loci. Gusmão descreve em detalhes a prática de compositio loci proposta por Loyola em seus Exercícios espirituais (LOYOLA, século XVI/1982). Este método consiste em representar na imaginação o mistério a ser meditado, colocando-se mentalmente no lugar onde o fato aconteceu ${ }^{4}$. Na novela, o uso deste método é descrito quando Predestinado, entrando numa sala do Palácio de Desengano chamada de Composição de Lugar, recebe um quadro pintado representando uma cena evangélica e oferece-o para três virgens chamadas: Memória, Inteligência e Vontade. Assim,

“fixos os joelhos em terra e o coração em Deus entregou o quadro à primeira Virgem Memória a qual depois de o reconhecer brevemente o entregou a Segunda Virgem Inteligência, a qual tanto com ele se deteve em o ver, rever e considerar muito devagar com mil discursos e considerações, que a terceira Virgem Vontade notavelmente se lhe afeiçoou e inflamou pelo ter e possuir, até que entregue por Inteligência o abraçou com uns abraços, que chama Propósitos tão apertados, que já mas lhe puderam arrancar do peito, ou para melhor dizer do coração" (1685a, p. 80).

\footnotetext{
${ }^{4}$ Gusmão dedicou à explicação da composição de lugar um texto: Meditaçôes para todos os dias da semana, pelo exercício das três potências da alma, conforme ensina santo Inácio que redigiu em 1689.
} 


\section{Ordenação dos afetos e da vontade pelo exame de consciência}

A ordenação dos afetos (apetites sensitivos) e da vontade (apetite intelectivo) deve remediar a desordem que ocorre quando os apetites se aliam com a fantasia (ou imaginação, que vimos ser um dos sentidos internos). O desvio desta posição é resumido por uma fala de Predestinado ao comentar a condição de Precito: "ter gozado como fins do que devia ser usado como meios" (p. 189) tendo por efeito é a confusão "com mil tristezas, desgostos e inquietaçôes" (p. 243). Esta desordem ocorre seja no nível individual, seja no nível social. Terapeuta indispensável para estes desmandos é "uma velha curandeira, que somente o sabe curar, a que chamam Mortificação da Vontade" (1685a, p. 189).

Predestinado cuida da ordenação de si mesmo, por obra de dois filhos "Rendimento do Juízo" e "Sujeição de Vontade" (1685a, p. 123). Assim, é aberto o acesso à virtude central para os jesuítas, a obediência: "Entrou, pois, Predestinado com Rendimento de Juízo e Sujeição da Vontade ao quarto de Obediência, que se chamava Coração Humilde" (p. 135). Conforme à visão inaciana, a obediência encontra fundamento na filosofia humana (aristotélica) e confirmação no preceito divino: Obediência declara ao Peregrino de ter "dois nascimentos": "o primeiro é Natural, deste sou filha de Vontade Santa e de Entendimento Rendido. O segundo nascimento é moral e por isso sou filha de Preceito e de Justa Lei” (1685a, p. 185). A obediência é virtude fundamental para ordenar a vida social e política.

Gusmão apresenta em pormenores a prática do exame de consciência e sua função na ordenação da pessoa e no conhecimento de si, conforme à tradição jesuítica. O exame de consciência voltado para o conhecimento de si mesmo tem diferentes etapas: exame particular, avaliação das intenções, visão de si, conversão sincera e diálogo com o médico espiritual. O exame define-se também como um "aparelho" preordenado ao exercício de um ato religioso, ou seja, um dispositivo colocado para possibilitar o recebimento do sacramento da confissão. Diversas potências psíquicas são mobilizadas pela ação do exame: lembrança, consciência, memória, desejo. $\mathrm{O}$ exercício destas potências acontece diante de determinado conteúdo que propicia a comparação entre a experiência histórica e concreta do sujeito e a experiência modelar proporcionada pelos "mandamentos de Deus", comparação "posta em lembrança”. Assim, o "cubículo retirado", os "livros", a vela, a imagem de Cristo crucificado, são elementos dispostos no ambiente em que acontece a prática, voltados a facilitar o dinamismo interior. Ao mesmo tempo, são metáforas de disposiçôes internas ao sujeito e indispensáveis para que ocorrer o exame: lembrança, consciência, memória, desejo, narrativa de sua própria história e conhecimento dos mandamentos divinos. Depois do entendimento, mobilizam-se os afetos, pelo uso de recursos voltados a proporcionar efeitos sensoriais: cores escuros, imagens, lagrimas, gestos:

"Passaram a uma recamara algum tanto escura como em sinal de sentimento onde viram a uma belíssima e honestíssima donzela toda vestida de luto sem ornato ou afeite algum, a qual estava de joelhos aos pés de um Crucifixo feita uma Madalena toda banhada em lágrimas, com uma mão batia nos peitos com uma pedra, com a outra estava presa com a mão direita de Cristo, de cujos olhos e boca saía um raio de luz que lhe penetrava o coração, no qual estava escrito: Tibi soli peccavi, e debaixo dos pés tinha o globo do mundo com esta letra: omnia." (1685a, p. 202) 
Desse modo, os recursos culturais que acompanhavam as práticas religiosas, tais como imagens sagradas, pinturas, músicas, enfeites, proporcionavam aparelhos para auxiliar o processo subjetivo do desengano (MASSIMI, 2005): estimulando os sentidos de modo a mobilizar os afetos.

Depois disto, Predestinado passa a sala da confissão propriamente dita onde o confessor, ou seja, o médico da alma, lhe proporciona as mezinhas, ou seja, os remédios espirituais. A seguir em outra sala o efeito desta prática sacramental é reforçado pelos exemplos de vários santos. Aqui de novo, a importância do exemplo é recolocada como experiência modelar onde se espelhar e conformar. $\mathrm{O}$ exemplo remete a atitudes que dizem respeito ao interior: da sinceridade do conhecimento de si e dos afetos associados depende a eficácia do sacramento. A importância da disposição subjetiva é colocada de modo claro e acreditamos ser este um dos indícios da introdução pelos jesuítas da perspectiva de uma dimensão interior já moldada pela cultura da nascente modernidade.

Segundo Gusmão, a penitência, mais do que ações de arrependimentos e gestos de grande intensidade emocional, consiste numa modalidade de vida regida pelo equilíbrio entre as virtudes: A "Penitência justa" é uma "mesurada Senhora" que dispõe na existência da pessoa, meios para ordenar os sentidos e afetos ao seu fim ultimo. De fato, a moderação é recomendada por Loyola, inspirado na prudência aristotélico-tomista (LOYOLA, 1982).

\section{Conhecimento e ordenação das disposições individuais pelo exame particular}

Outro importante recurso para a ordenação da vida anímica na tradição jesuítica é o exame particular. O Padre Geral Cláudio Acquaviva, no documento Instructio ad reddendam rationem conscientiae iuxta morem Societatis Iesu (1593) institui oficialmente como "perpetua praxe" da Companhia, a prática do exame de consciência, cujo objetivo é de obter "o mesmo efeito à alma, que ao corpo a medicina" (1593/1893, p. 35) e cujas funções são: o autoconhecimento, a prevenção dos afetos desordenados, o cuidado de si mesmo, a descoberta das diferenças individuais. A prática se funda no pressuposto de que "são diferentes os movimentos interiores do homem: existem os tímidos, os audaciosos, os coléricos etc". De modo que, "o examinado deve dizer qual é a paixão que mais o afeta e o aflige: se for colérico, qualquer coisa mínima o perturba; se for tímido, espanta-se por qualquer pequeno acidente" (1593/1893, p. 34).

$\mathrm{Na}$ novela de Gusmão, o protagonista é convidado a realizar o exame particular quando ele chega à cidade de Bethel: aqui ele deve percorrer a chamada "via purgativa", que implica um tipo de conhecimento de si chamado de exame particular, investigação acerca dos hábitos e costumes, "remédio (...) do qual usava três vezes ao dia, em que facilmente acabou de desarraigar todas aquelas raízes de maus costumes e hábitos ruins" (1685, p. 259).

\section{A presença do médico espiritual}

O emprego de todos estes recursos para a ordenação da vida pessoal, sempre pressupõe a presença ativa do médico espiritual. O já citado Cláudio Acquaviva (1543-1615), 
um dos sucessores de Inácio na direção da Companhia, foi autor das Industriae ad curandos animi morbos (Normas para a cura das enfermidades do ânimo, 1600; ed. 1893), destinado a todos os Superiores da Companhia visando à orientação da formação espiritual de seus discípulos. Neste texto, Acquaviva retoma a analogia tradicional entre doenças e cura do corpo e enfermidades e terapia da alma, define vários tipos de doenças espirituais e de remédios para cada uma e institucionaliza a função do médico espiritual. A partir de Acquaviva, o rotulo Medicina da Alma comparece sistematicamente na literatura jesuítica: trata-se de um conhecimento do ser humano e de sua dinâmica psicológica visando à adaptação deste ao contexto social de inserção (a comunidade religiosa e o ambiente em que esta desenvolve sua missão no mundo).

Na novela de Gusmão, ainda no percurso da "via purgativa", diante da impossibilidade de corrigir por conta própria todas as faltas e imperfeiçōes da conduta, o Peregrino é encomendado a "um médico muito experimentado e perito nos ataques do espírito a quem chamam Padre Espiritual, para que tivesse cuidado de lhe aplicar os frutos, folhas, flores conforme pedisse sua necessidade". Para ele, o Predestinado devia "descobrir-lhe todos seus ataques, dores e enfermidades, ainda sua compleição natural e inclinaçôes para poder ser dele curado segundo a necessidade de seu presente estado". Gusmão comenta que esse "médico" era tão apreciado que nele depositava-se "todo o feliz sucesso dos Peregrinos que moravam neste bairro, isto é, todo o aproveitamento dos principiantes na vida espiritual" (1685, p, 265).

\section{CONCLUSÃo}

A condição humana é entendida pelos jesuítas no âmbito de sua visão de mundo teológica e filosófica, como sendo marcada por uma temporalidade orientada na direção de um destino final. A liberdade, dimensão constitutiva do dinamismo humano, torna o mesmo homem protagonista ativo desta temporalidade. No âmbito da tradição judaico-cristã esta concepção encontra expressão na figura da vida como peregrinação, enredo da novela. Todavia, a peregrinação deve ser entendida não apenas na perspectiva do universo conceitual como também no universo das práticas. Com efeito, neste âmbito a peregrinação é uma ortopraxis que, utilizando-se de vários dispositivos retóricos, visa modelar a experiência da pessoa de modo a torná-la mais adequada a realizar seu destino ideal; e, portanto, ao uso adequado de sua liberdade para conseguir tal fim. Nesta perspectiva, os jesuítas se inserem com sua proposta de atuação, que inclui a pregação, pedagogia e a medicina do ânimo, dentre outros. Segundo eles, a pessoa realiza seu destino pelo bom emprego de suas disposiçõos e dentre elas a vida anímica tem uma função fundamental de articulação entre a dimensão corporal e a espiritual. O conhecimento da vida anímica leva ao objetivo pratico de sua ordenação, à qual tarefa os jesuítas dedicam todo seu empenho. Em suma, os saberes psicológicos dos jesuítas visam a incorporação da pessoa ao todo, mobilizando e exercitando sentidos, afetos, juízo e vontade, corpo e alma, segundo um percurso pedagógico orientado para a realização do fim último e direcionado pelo médico espiritual. No Brasil, trata-se do projeto da criação do "corpo social cristão", conforme uma expressão freqüentemente utilizada por Manuel da Nóbrega em suas cartas, onde português, índio, escravo, mestiço são integrados. Trata-se da formação da "República 
cristã", objetivo do empenho pedagógico dos jesuítas, conforme frisa Gusmão, em outra sua obra, $A$ arte de criar bem os filhos na idade da puerícia (1685, prólogo ao leitor).

\section{REFERÊNCIAS}

ACQUAVIVA, C. - Industriae ad curandos animi morbos [Manuscrito]. 1893. F. 33-42. Acessível em ARSI. Ms. 429 da Opera Nostrorum. Acessível também em Institutum, vol. 2.

ACQUAVIVA, C. - Instructio ad reddendam rationem conscientiae iuxta morem Societatis Iesu [Manuscrito]. 1893. F. 33-42. Acessível em ARSI. Ms. 429 da Opera Nostrorum. Acessível também em Institutum, vol. 2.

AGOSTINHO DE HIPONA - A Trindade. Trad. de A. Belmonte. São Paulo: Paulus, 1994. Original do ano 414. ARISTÓTELES - Rethorique. Paris: Belles Lettres, 1993. Vol. 2. Original do século IV a.C.

- Problemata XXX. In Problémes. Paris: Les Belles Lettres, 1994. Vol. 3

- Ética a Nicomaco. Livro segundo. [S.1.]: Edição Pensadores [etc.], 1996. Original do século IV a.C.

- De Anima. Apres., trad. e notas de M.C.G. dos Reis. São Paulo: Editora 34. Original século IV a.C.

BETTENDORF, J.F. - Crônica da missão dos padres da Companhia de Jesus no Estado do Maranhão. Rio de Janeiro: IHGB/Imprensa Nacional, 1919. Original escrito em 1687.

FRANCISCO DE BORJA, Santo, 1510-1572 - El evangelio meditado; meditaciones para todas las dominicas y ferias del año y para las principales festividades. Madrid: Administración de Razón y fe, 1912. Obra inédita compuesta por San Francisco de Borja de la Compañia de Jesús, sacada del origina corregido de mano del santo por el P. Federico Cervós.

BUNJAM, J. - O peregrino. A viagem do cristão à cidade celestial. Trad. A.H. Silva. São Paulo: Editora Martin Claret, 2004. Original publicado em 1678.

BUZZI, F. - Teologia e cultura crisitana tra XV e XVI secolo. Genova: Marietti, 2000.

CARDINI, F. - Gerusalemme d'oro, di rame, di luce. Pellegrini, crociati, sognatori d'Oriente fra XI e XV secolo. Milano: Il Saggiatore, 1991.

CARRUTHERS, M. - Machina memorialis. Meditazione, retorica e costruzione delle immagini (400-1200). Trad. de L. Iseppi . Pisa: Edizioni della Normale, 2006. Original publicado em 1998.

CERTEAU, M. de - A escrita da história. Trad. M.L. Menezes. São Paulo: Editora Forense, 2000. Original publicado em 1975.

ELIADE, M. - Paradiso e utopia: Il messianismo nella società americana. I Quaderni di Avallon: Rivista di studi sull'uomo e sul sacro. № 24 (1991), p. 29-50.

GIARD, Luce - Les jésuites á la Renaissance. Système éducatif et production du savoir. Paris: PUF, 1995. (Bibliothèque d'histoire des sciences).

GIARD, Luce; Vaucelles, Louis de - Les jésuites à l'âge baroque, 1540-1640. Grenoble: J. Million, 1996 (Historie des jésuites de la Renaissance aux Lumieres).

GOIS, Manuel de - Commentarii Collegii Conimbricensis Societatis Iesu, In libros Aristotelis qui Parva Naturalia appellantur. Lisboa: Simão Lopes, 1593.

- Disputas do curso sobre os livros da moral da ética a Nicomaco, de Aristóteles em que se contêm alguns dos principais capítulos da Moral. Trad. A.B. Andrade. Lisboa: Instituto de Alta Cultura, 1957. Original publicado em 1593.

- Commentarii collegii conimbricensis Societati Iesu, In tres libros de anima. Veneza: [S.n], 1602.

- Commentarii collegii conimbricensis Societatis Iesu, In Libro de generatione et corruptione Aristotelis Stagiritae nunc recens omni diligentia recogniti et emendati.Veneza: Tipografia Vincenzo Amadino, 1607.

GUSMÃO, Alexandre de - História do Predestinado Peregrino e de seu Irmão Precito. Lisboa: Deslandes, 1685.

- A arte de criar bem os filhos da idade da puerícia. Lisboa: Deslandes, 1685.

- Eleyçam entre o bem e o mal eterno. Lisboa: Officina da Musica, 1720.

LOYOLA, Ignacio de - Obras completas. Madrid: [s.n.], 1982. (Bibliotecas Autores Cristianos; no 86

- Cartas. São Paulo: Edições Loyola, 1993.

- Autobiografia. Trad. de A. Cardoso. São Paulo: Edições Loyola, 1991. Original de 1555.

MASIMI, Marina - Deletare, movere et docere: retórica e educação no Barroco. Per Musi. Universidade Federal de Minas Gerais. Vol. 17, (2008), p. 54-59.

- Estudos sobre a contribuição da antiga Companhia de Jesus ao desenvolvimento dos saberes sobre o psiquismo. CLIO. [S.l. : s.n.]. Vol. 2, (2009), p. 163-191. Série História do Nordeste, UFPE.

- Imagens da natureza e afetos humanos em sermões brasileiros dos séculos XVII e XVIII. In Imagens da Natureza. Lisboa: Apenas, 2008. 
- Imagens da natureza na pregação jesuítica em Terra Brasilis. In A natureza nos Novos Mundos. Lisboa : Apenas, 2007, p. 28-47.

- Imagens, dinamismo sensorial e elaborações retóricas no Brasil colonial. Interamerican Journal of Psychology. [S.l. : s.n.], Vol. 43, (2009), p. 374-382.

- As imagens e sua função no dinamismo anímico dos ouvintes: percorso da oratória sagradas brasileira do século XVI ao XVIII. In A Fábrica do antigo. Campinas: Editora Unicamp, 2008. p. 303-328.

- Palavras, almas e corpos no Brasil colonial. São Paulo: Ediçôes Loyola, 2005. 330 p.

- A pessoa e o seu conhecimento: algumas etapas significativas de um percurso. Memorandum. Belo Horizonte : [s.n.], Vol. 18, (2010), p.10-26.

- La psicologia dei temperamenti nei Cataloghi Triennali dei gesuiti in Brasile. Physis, Rivista Internazionale di Storia della Scienza. [S.1 : s.n.], Vol. 37, 1, (2000) p. 137-149.

- A Psicologia dos jesuítas: Uma contribuição à História das Idéias Psicológicas. Psicologia. Reflexão e Crítica. [S.l. : s.n.] vol. 14, (2002), p. 625 - 633.

- Il Potere e la croce: colonizzazione e riduzioni dei gesuiti in Brasile. Milano: Edizioni San Paolo, 2008. 209 p.

- A teoria dos temperamentos e suas aplicações nos trópicos. Ribeirão Preto: Editora Holos, 2010. 80 p.

- A teoria dos temperamentos na literatura jesuítica nos séculos XVI e XVII. Lisboa: [S.n.], 2000 vol. 6-7, p. $223-236$.

MASIMI, Marina ; BARROS, Mariana Leal de - Releituras da Indiferença: um estudo baseado em cartas jesuíticas dos séculos XVI e XVII. Paideia. Vol. 15, (2005), p. 195 - 206.

MASIMI, Marina ; CONDE, Renata de Lima - Corpo, sentidos e coreografias: narrativas de uma festividade na Bahia do século XVIII. Psicologia em Revista. Vol. 14, (2008), p. 215-234.

MASIMI, Marina ; PRUDENTE, André Barreto - Um incendido desejo das Índias. São Paulo: Loyola, 2002. $111 \mathrm{p}$.

MASIMI, Marina; SILVA, Paulo José Carvalho da - Os olhos vêem pelo coração. Conhecimento psicológico das paixões na história da cultura brasileira dos séculos XVI a XVII. Ribeirão Preto : Holos Editora, 2001. 124 p.

NÓBREGA, Manuel da - Cartas do Brasil. Belo Horizonte: Editora Universidade de São Paulo [etc.], 1989. Col. Reconquista do Brasil, n. ${ }^{\circ}$ 147; original de 1551.

OURSEL, Raymond - Pellegrini del Médio Evo : gli uomini, le strade, i santuari. Trad. A. Monti. Milano: Jaca Book, 1979. Original publicado em 1978.

PACHECO, Paulo Roberto de Andrada; MASSIMI, Marina - A experiência de obediência nas Indipetae. Memorandum. Belo Horizonte : [s.n.], (2009), Vol. 17, p. 22-44.

- Liberdade e indiferença: a "experiência modelo" jesuítica em cartas de jovens indipetentes espanhois dos séculos XVI e XVII. In Pesquisas em psicologia: múltiplas abordagens. São Paulo: Vector, 2009. Vol. 1, p. 15-54.

- O conhecimento de si nas Litterae Indipetae. Estudos de Psicologia. Vol. 10, (2005), p.345 - 354.

SANTOS, Zulmira - Emblemática, memória e esquecimento: a geografia da salvação e da condenação nos caminhos do "prodesse ac delectare" na história do predestinado peregrino (1682) de Alexandre de Gusmão SJ [1629-1724]. In COLÓQUIO INTERNACIONAL A COMPANHIA DE JESUS NA PENÍNSULA IBÉRICA NOS SÉCULOS XVI E XVII. Porto : Universidade do Porto [etc.], 2004. p. 581-600.

TOMÁS DE AQUINO, Santo - Suma Teológica. Trad. de C.P. de Oliveira. São Paulo: Edições Loyola, 2001. Original de 1273. 